\title{
Transnational connectivity, cultural interaction and selective adaptation: English Corinthians and amateur football in the
}

Netherlands, c.1906-39

'There was the usual exodus from town yesterday', the Sportsman reported at Easter 1906, '... and by the half-past eight train from Liverpool-street - which was so packed that the corridors were occupied - the Corinthians and Richmond Wanderers took their departure for the Continent. ${ }^{1}$ Of the many clubs venturing abroad in this period, the Corinthians were by far the most famous. Having toured South Africa in 1897 and 1903, following the imperial sporting pathway trodden a little earlier by English cricketers and rugby footballers, their fixtures now included matches played on short expeditions to 'the Continent', as the English liked to refer to Europe. They had played in Budapest, Vienna, Prague and Leipzig in March 1904 and Gothenburg, Uppsala, Stockholm and Copenhagen a few months later. In 1906 they were heading for Germany and the Netherlands, where their arrival was eagerly anticipated, not least by Amsterdam's De Telegraaf. 'That which we have desired for years will become a reality today and tomorrow ... The Corinthians, the elite of the English game, the amateurs, stronger than the best professionals, will come and show us what football is and how that game should be played.' ${ }^{2}$ For club secretary B. O. Corbett, who played in three of the four matches on the 1906 tour, such initiatives helped to popularize 'the British ideal of sportsmanship' while breaking down 'that insular prejudice which we both acknowledge and deplore. ${ }^{3}$ Their tours were never just about football. The Corinthians saw themselves - and were often seen by others - as the embodiment of gentlemanly amateurism.

'The standard theory', according to Maarten van Bottenburg, 'is that Britain is the birthplace of modern sports and that sports diffused from the homeland to the rest of the world. ${ }^{\prime 4}$ As Bill Murray's history of world soccer pointed out, 'there was almost always a British connection somewhere, in the fine details as much as the broad sweep. ${ }^{5}$ Recent scholarship has located the diffusion process within the wider context of sports 
globalization. 'The game's genealogy', Giulianotti and Robertson have observed in relation to soccer, 'is closely interwoven with broader globalization processes.' ${ }^{6}$ Historians are now inclined to argue that British sports were not the only beneficiaries of the diffusion process; that sports were diffused from a plurality of centres; and that soccer globalization rested on a complex web of connections that worked in more than one direction. Tours undertaken by British teams remain an important part of the story but the emphasis now is on connectivity and the cultural interaction that such events generated. ${ }^{7}$ Thus it is important to understand why particular elements in Dutch society welcomed England's elite amateurs so enthusiastically and to recognize the possibility that reverse diffusion was already taking place, albeit on a limited scale. As the Corinthians travelled to the Netherlands in 1906, Rotterdam Sparta were already in England on their own four-match tour. ${ }^{8}$

There are, however, dangers in looking at the past through the wrong end of the telescope. Matthew Taylor has pointed to 'the present-centred focus of the majority of existing accounts of the globalization of sport' and the need 'to deepen our historical understanding of globalizing processes. ${ }^{\prime 9}$ The matches played by the Corinthians in the Netherlands are best understood in relation to the immediate context in which they occurred rather than by linking them to an unfolding saga of sports globalization. Geoff Hare, referring to early encounters between English and French clubs, notes that the press often used the adjective 'international' to describe such matches but urges caution. 'We must be wary', he argues, 'of interpreting what was happening as conscious attempts to move towards "international competitions" or European cups at club level as we know them today. ${ }^{\prime 10}$ Similarly, accounts of the Corinthians on tour in the Netherlands should not be overburdened with knowledge of what came later. Yet there is much to be gained from archive-driven research into these transnational sporting encounters as indicated by Matthew McDowell's recent work on tours by Scotland's Queen's Park to Denmark. ${ }^{11}$ It facilitates a reading of the development of globalized sport that is both nuanced and grounded. Tony Mason's contribution to this area of inquiry, especially his critique of the conventional wisdom that British football was insular in its outlook, demands to be taken seriously. Insularity, he argues, may have been 'an important presence at the formal level of 
national associations'; however, 'at the informal level of individuals and clubs, the practice could be somewhat different.' 12

There are other reasons for embarking on this exercise. Teams on tour 'were often represented as both sporting and cultural ambassadors.' ${ }^{13}$ The Corinthians certainly travelled with a good deal of cultural baggage, much of it bundled together loosely and packaged as amateurism, always as much about behaving like an idealized version of a public-school educated English gentleman as engaging in sport for love rather than money. ${ }^{14}$ Amateurism, like association football, originated in Britain before transcending national boundaries and establishing itself as a global phenomenon, 'a near universal value', in Lincoln Allison's phrase. Again, it would be naïve to regard its diffusion as a simple one-way process. Cultural interaction was part of the touring experience, its particularities determining outcomes. Thus 'the sense of amateurism and the degree to which amateurism was accepted varied from place to place. ${ }^{15}$ Positive representations of the visitors in Dutch newspapers often reflected contemporary enthusiasm for all things English, a sentiment especially prevalent amongst those who 'because of their origins, profession, or education, were part of larger networks than the local and regional structures within which most people's lives were confined.' In a country where cricketers posed casually for team photographs like English gentleman enjoying a country-house weekend the Corinthians and what they represented were likely to be well received. ${ }^{16}$ Yet Dutch attitudes to their distinguished guests were essentially pragmatic; selective appropriation and adaptation rather than slavish imitation was the predominant theme.

Our intention is to make use of English and Dutch-language primary sources, principally contemporary newspapers, to explore the issues outlined above, firstly from the perspective of the Corinthians and secondly from that of their Dutch hosts. Though historians of sport are sometimes criticized for over-reliance on such sources it would be perverse to neglect them. This does not mean that evidence derived from newspapers should not be evaluated according to the same protocols that historians apply to other surviving fragments of the past. It is important, for example, to recognize that reporting in Het Volk or Voorwaarts in the 1920s reflected the left-wing stance of these newspapers and that this underpinned their sympathetic coverage of the working-class volksclubs which 
many of their readers followed. Other primary sources also have their uses if read with sensitivity to the particularities of historical context. Extensive coverage of the schism in English amateur football between 1907 and 1914 in Nederlandsche Voetbalbond (NVB) yearbooks suggests that it resonated powerfully in Dutch football circles. 'As far as our relationship with England is concerned', it was noted in 1908, 'the further development of events is for us of the greatest importance. ${ }^{17}$ Again, bilateral cultural interaction rather than global diffusion is the key issue here.

\section{English gentlemen on tour}

George Wyndham, ardent imperialist and Conservative MP, was aware of living 'at a time when facilities of transit are being multiplied and cheapened'. This made him so anxious that he warned university students in 1904 of the dangers attached to 'polyglot restaurants', 'international sleeping cars' and 'cosmopolitan luxury' in general. 'It makes for satiety and slumber', he argued, 'and slumber, if unduly prolonged, invites a rude awakening. ${ }^{18}$ It seems unlikely that Wyndham had the growing numbers of soccer tourists in mind when making this speech. If so, such criticism would have been unfair for they were often committed to demanding schedules that left little time for sleep. In 1900, Upton Park, slotted the match in Paris for which they were subsequently awarded Olympic gold into a schedule of ten games in 14 days played in England, France and the Channel Islands. ${ }^{19}$ Yet, though sports tourism could be arduous, it grew steadily in the late-nineteenth and earlytwentieth century, with 'better-off amateur sides' from Britain especially well-placed to take advantages of expanding opportunities to travel. ${ }^{20}$ Sport supplied the pretext but there were other aspects of touring to be enjoyed. Significantly, Wyndham, despite his anxieties, discovered that foreign travel with like-minded male companions offered an escape from 'stifling domesticity' and it would be unwise to underestimate the attractions of the social side of sports tourism. ${ }^{21}$ These were enhanced when the hosts were attentive, flattering and belonged to the same social class as their guests.

By the time of the first visit by the Corinthians in 1906 the Netherlands was already a destination favoured by touring parties from England. From the early 1880s 'English cricket teams visited the Netherlands almost every year, providing an excellent opportunity for Dutch players to observe and copy their behaviour. ${ }^{22}$ Such teams invariably comprised 
gentleman amateurs like the Reverend E.E. Lee, for whom touring offered opportunities each summer to enjoy sport in congenial company and mildly exotic surroundings. Lee, who had captained his public-school eleven before going on to play at Oxford, set aside his duties as a clergyman to play for the Gentlemen of Worcestershire at Amsterdam, Haarlem and The Hague in $1895 .{ }^{23}$ English soccer clubs began travelling to the Netherlands to play Dutch opposition in the mid-1890s. Harwich and Parkstone was first, visiting Rotterdam Sparta in 1893 and 1894. Felixstowe followed, travelling to Rotterdam twice in 1894 and playing four matches, the last against a 'Holland $\mathrm{XI}^{\prime}{ }^{24}$ That teams from coastal ports should lead the way underlines the importance of trade routes in transnational diffusion. The English Wanderers, described by the Morning Post as 'a scratch team consisting of well-known Southern players', toured four times between 1896 and 1899, playing up to seven matches on consecutive days. ${ }^{25}$ Win or lose, such encounters generated contacts between players and officials which facilitated further engagement. The English Wanderers party in 1899 included W.U. Timmis, an Oxford soccer 'blue', who was already playing for the Corinthians and is credited by the club's historians for having arranged the 1906 tour. $^{26}$

N.L. ('Pa') Jackson, a journalist and sports promoter, had founded the Corinthians in 1882 to enable the best English amateur footballers to play together more often. He claimed in his memoirs that his aim was to improve the performance of the England team in the annual match against Scotland. From the start there was 'an unwritten law confining election to Old Public School Boys or members of a university, playing merit, of course, being essential. ${ }^{27}$ Their emergence coincided with the rise of football as commercialized entertainment in the industrial North and Midlands where clubs began paying players in the hope of achieving success. In these conditions the Corinthians rapidly became the standardbearers for amateur soccer as played by public-school 'old boys', 'varsity men' from Oxford and Cambridge, and young middle-class men making their way in the professions in and around London. Jackson brought his teams together at Christmas and Easter when they toured the North of England and Scotland, taking on and sometimes beating famous professional clubs in challenge matches often characterized as contests between two sporting worlds, each with its own distinctive ethos. The Morning Post has been described as 'an intrepid champion of lost causes, most of which deserved to be lost', but was not 
alone in looking to the Corinthians 'for a maintenance of the true traditions of football in these days when the sport is overrun by a great wave of professionalism.'28 This involved more than simply upholding the amateur tradition. It was also about maintaining the prestige of the social elite from which this most exclusive of clubs drew its players.

When assessing how far the Corinthians succeeded in achieving this objective excessive claims made by admirers and apologists should be discounted. ${ }^{29}$ It is sufficient to note that in the first 25 years of the club's existence it won enough one-off matches against professional opposition to perpetuate a reassuring illusion of gentlemanly superiority. There were some famous victories, especially in the mid-1880s, and a spectacular 10-3 win over FA Cup-holders Bury in 1904, though recent research by Terry Morris suggests an overall performance characterized by inconsistency rather than excellence. The most significant reverse suffered by the Corinthians, however, happened off the field of play and was entirely self-inflicted. The decision to quit the Football Association (FA) in 1907 and join the Amateur Football Association (AFA) was ill-judged, leaving the club stranded in a footballing backwater. A subsequent FA edict prohibiting matches against AFA clubs was especially damaging because it denied the Corinthians high-profile friendlies against professional opposition. Though English football's 'great split' was short-lived - the secessionists returning to the FA in 1914 - it marked a significant watershed. When play resumed after the First World War 'Corinth', as true-believers liked to refer to the famous club, was already in decline. Matches in the FA Cup, in which the Corinthians competed for the first time in 1922, supplied only tantalizing glimpses of former glories. Yet, for as long as the club existed it could be honoured as the embodiment of a socially-elite version of amateurism which continued to command a degree of support at home and abroad, not least in the Netherlands. ${ }^{30}$

So what did playing the game like a Corinthian entail? Though past their best by 1906 and a fading force by the 1920s, admirers claimed that they played with an attacking flair that risk-averse professionals could not match. 'The forward play was most delightful', ran a sympathetic report after the 1905 Christmas tour, "being in striking contrast to the stereotyped variety we get in League football. ${ }^{31}$ Comment in the Dutch press often reflected this assessment creating an expectation that the visitors would attack with style, 
pass with precision and treat spectators to an exhibition of football at its very best. 'The Corinthians are stronger than any professional club in England this year', claimed Algemeen Handelsblad when the 1906 tour was announced. 'Everyone wants to see these English masters play', observed De Telegraaf when they finally arrived. Even in the 1920s the Nieuwe Rotterdamsche Courant could anticipate 'that something beautiful will be seen ... as the Corinthians can still demonstrate a game which no other team can touch. ${ }^{\prime 32}$ Ten years later when Haagsche Voetbal Vereeniging (HVV), was planning its fiftieth anniversary celebrations, it was anticipated that a match against the Corinthians 'would undoubtedly be one of the highlights of the programme.'33

The idea that it was possible to play football while behaving like a gentleman was one with which the Corinthians had long been associated. They saw themselves as upholding 'the honourable code of the true amateur'. ${ }^{34}$ R.C. Gosling, a Corinthian of the 1890s, epitomized this ideal type. On his death it was recalled that he had been 'graceful' as a player, 'never ungenerous in action or unkind in word' and that he was 'ever the English gentleman' ${ }^{35}$ When considering tours in the 1920s in particular, it is important to note the social tensions then impacting on the game in the Netherlands and 'protests by the socalled upper-class clubs against the perceived rough and ungentlemanly conduct of the lower-class clubs. ${ }^{36}$ In these circumstances the role assigned to the Corinthians was to provide reassurance by demonstrating that football as it had been played by gentlemen amateurs like Gosling still had something to offer. There was some awareness in the Netherlands in the early 1920s that the club's status in English football was not what it once had been. 'Their time is over', was the Nieuwe Rotterdamsche Courant's verdict in 1920 on many of the players and perhaps also on the club itself. Yet, as the same newspaper conceded two years later, the Corinthians were welcome visitors because they were 'sportsmen in the best sense of the word ... They play hard, but never rough and one can expect no unfair practises from them.' 37 The implication was that a visit from the Corinthians would help the gentlemen amateurs of the Netherlands retain the moral high ground as they struggled to maintain their position within the domestic game.

Being an English Corinthian almost inevitably involved being a sports tourist whether at home or abroad. With no permanent base until 1922, the Corinthians made a virtue of a 
nomadic existence that underpinned their status as gentlemen amateurs. 'The club has never possessed a ground of its own', explained C.B. Fry in 1906, 'and has never had to consider finance. ${ }^{\prime 38}$ This was disingenuous as tours had to be financed, the Corinthians sometimes attracting criticism on account of substantial guarantees demanded from their hosts and for pushing the boundaries of the $F A^{\prime}$ 's regulations regarding legitimate expenses. ${ }^{39}$ Though Corinthian tourists were expected to pay for drinks, it seems unlikely that they had to reach into their own pockets very often, especially when abroad, as much wining and dining was at the expense of their hosts. In the Netherlands the guarantees were sufficient to cover accommodation at comfortable hotels accustomed to catering for a middle-class clientele. At The Hague in 1906, Corbett recorded, 'we put up at the Bellevue, a most comfortable hotel overlooking the deer-park.' There was usually time for sight-seeing - 'we passed an almost continuous succession of hyacinth and daffodil fields' - and the 1922 and 1923 touring parties seized opportunities to play golf at Noordwijk. The social whirl brought occasional perils, but they were minor. At a banquet in their honour at the British Embassy in 1923, one Corinthian was 'cornered by a Dutch titled lady, who discoursed long on the glories of Eton, with touching appeals to him to use his influence to get her son entered there, before she discovered that [he] was at Winchester.' ${ }^{40}$ Corbett observed in relation to the club's tours in England that 'the social element was more pronounced' from the 1890 s onwards. By the early 1920 s it was very much in the ascendant on oversea tours too. As Morris has argued, the Corinthians 'had become a club in which well-to-do gentlemen enjoyed one another's company, and played a bit of football in the process. $^{41}$ This may be a little harsh but the tendency was in that direction and has to be factored into any understanding of the Anglo-Dutch cultural interactions that ensued.

\section{Dutch soccer and Corinthianism before 1914}

Their faces may have been unfamiliar but when the Corinthians ran out to play HVV at The Hague in April 1906 local soccer enthusiasts were already aware of their formidable reputation. Just before the turn of the century the Dutch press had begun to devote serious attention to sport and this meant responding to the growing interest in soccer. It was now possible for readers to keep up with the latest developments in England and the Corinthians often featured, as in 1897, when Algemeen Handelsblad alerted readers to their 
forthcoming South African tour. ${ }^{42} \mathrm{~A}$ year later, the same newspaper noted regretfully that attempts by the R.U.N. Amstels Progress (RAP) club to bring the famous amateurs to Amsterdam had been unsuccessful; in 1903 a similar initiative by the NVB also failed. ${ }^{43}$ Yet, while denied opportunities to see the Corinthians in action, readers in the Netherlands were able to follow their exploits at home and abroad. They could only have been impressed by a report in 1904 that the Corinthians had won three matches in Budapest, scoring 28 goals and conceding none. ${ }^{44}$ News of a $12-0$ victory in London over a Belgian representative $\mathrm{XI}$ in January 1906, a few months before the Corinthians set out for the Netherlands, simply made it easier for anglophile football journalists - often closely involved with the Dutch game at national, regional or club level - to idealize their eagerly-awaited visitors.

As the date of their arrival approached the Dutch press made it clear to soccerminded readers that they were about to witness something rather special. Algemeen Handelsblad reported a win over Manchester City 'in which the Corinthians displayed their mastery', even if the final score had been 'somewhat flattering'; Nieuws van der Dag recycled an article that stressed the power, speed and efficiency of the Corinthians forwards and the resilience of its defence; spectators could expect to see 'plenty of hard [shoulder] charging' but this would never descend into 'rough or nasty play'. ${ }^{45} \mathrm{~A}$ brief account of its history, 'taken from one of the English magazines', left readers in no doubt that the Corinthians were 'the best amateur club in England', selecting only from those who had proved themselves in their public school and university teams. 'It goes without saying that such a club always has the best resources at its disposal', it explained. If they were sometimes defeated, it was because some team members held positions of responsibility 'whereby they are not able to play regularly every Saturday. ${ }^{46}$ Thus the sports pages helped to ensure that the Corinthians arrived surrounded by an aura of invincibility, not simply a football team but an example to be followed, amateurs in a sea of professionals, a seductive blend of social superiority and winning ways.

The Dutch sporting press captured the mood. 'They were then in our midst, these sons of Albion', declared the NVB's Het Sportsblad, 'the crème de la crème of English football, who a few days ago beat Aston Villa - the club of which we dreamed in our younger days - by 7-1, who this week in Germany delivered a pair of celebrated blows 11-0 
and 12-2 in Berlin and Hamburg, and would now let us Hollanders see what real football is. ${ }^{\prime 47}$ That the Corinthians would defeat their Dutch opponents was never in doubt; it was simply a question of how many goals they would score. Yet, although they won both their matches, 5-1 against HVV and 2-1 against what was effectively the Dutch national side, they had to work harder for their victories than either they or their hosts had anticipated. They learned from the first match 'that football in Holland was at a much more advanced stage than in Berlin' and in the second found themselves confronted by 'a side which would have tested many [an English] First League team. ${ }^{48}$ As the excitement subsided reporters went in search of compliments and the visitors were happy to oblige, Timmis predicting that if they continue in this way, the Dutch will beat the best English amateurs in a couple of years. ${ }^{49}$ The performance of the 'All Holland' team in particular provided a pretext for optimistic speculation regarding a forthcoming international match against Belgium. 'Given that the Belgian team was beaten $12-0$ by the Corinthians and ours by only $2-1^{\prime}$, observed a Rotterdam newspaper, 'we can look forward with a sense of ease for our national honour to the meeting between Belgium and Holland. ${ }^{50}$ High hopes were soon to be dashed, however, as the national side lost twice to their closest rivals within the space of a fortnight before losing 8-1 to England's amateurs, thus prompting a crisis of confidence at the NVB and in Dutch football more generally.

In the ensuing debate, the focus was mainly on how to improve the performance of the national team, raising other issues that were to resonate powerfully over the next thirty years. The Belgians, it was noted, were better prepared than the Dutch because they 'trained' seriously. Why not follow their lead in this respect? Yet, as Het Sportsblad's editor C.J. Groothoeff argued, few Dutch players would want to adopt a similar approach, most being 'far too attached to their glass of beer and to their cigars'. Indeed, sacrificing these delights would mean that 'the pleasure of football [would] be somewhat lost', compromising its appeal as a sociable activity for young men unwilling to commit themselves to the disciplined regimes endured by athletes and oarsmen, not to mention Belgians. ${ }^{51}$ Groothoeff's intervention thus linked training to wider debates in Dutch football circles about what the game was for and who should be playing it. Ironically, the Corinthians, determined to sustain an illusion of effortless superiority befitting their 
elevated social status, were also disinclined to train. 'The Corinthians of my day never trained, and I can safely say that the need of it was never felt', recalled G.O. Smith who had played for them - and for England - around the turn of the century. ${ }^{52}$ This may help to explain why they, or perhaps their mythic representation, featured so prominently in the deliberations of the NVB's selection committee while travelling to another match against Belgium in April 1907. What was needed, they decided, was 'a club in the spirit of the English Corinthians'. ${ }^{53}$

This initiative - the projected new club was at first referred to in the press as the Hollandsche Corinthians - was supported by the NVB and the Dutch soccer establishment generally. At its inaugural meeting in July 1907 C.A.W. Hirschman, the NVB's representative at FIFA since 1904, restated the intention to found 'a club which in outline resembles the existing English Corinthian Football Club. ${ }^{54}$ Concerns were raised subsequently at a meeting of senior officials regarding potential conflicts of interest between De Zwaluwen (The Swallows), the name eventually chosen, and existing clubs, especially when arranging matches against touring teams. Celebrated referee Herman Tromp argued that Dutch players were unwilling to learn lessons from anyone and would resist the idea that they should practice so as to bring their skills up to a level comparable with leading English amateurs. It was clear, however, that the NVB was determined that the Swallows should fly and this supplied the necessary momentum. For Jaspar Warner, NVB president, the club just like its English counterpart - would serve the interests of Dutch soccer's 'Old Boys', providing them with an opportunity to raise their game outside the framework of the various league competitions which had emerged since the turn of the century. This was entirely compatible with the idea that the Swallows, by bringing the best players together more often, would help to improve the performance of the national team. ${ }^{55}$ The influence of the Corinthians and the sporting ideology they represented was evident throughout this episode but given a particular local construction.

It seems likely that this tendency was strengthened after 1907 when the Corinthians joined the renegade AFA thus precluding any possibility of building on the relationships established during the 1906 tour. ${ }^{56}$ The NVB, responding to a request from the FA, refused to sanction matches with AFA-affiliated clubs and it was fifteen years before the Corinthians 
played again in the Netherlands, though a victory was achieved against Queens Park, their Scottish counterparts, when they visited in 1913. Denied fixtures against English 'Old Boys', the Swallows fielded invitation elevens against representative sides from France and Belgium and against Dutch national, regional and military elevens. The first of these matches saw Edgar Chadwick, appointed by the NVB in 1908 to coach the national team after a long career in professional soccer, playing for the Swallows, a breach of the amateur code that would not have been permitted by the Corinthians, even though - as Llewellyn and Gleaves have observed - the British in this period were not always the pristine purveyors of amateurism that they sanctimoniously claimed. ${ }^{\prime 57}$ Meanwhile Dutch soccer continued to seek inspiration from across the North Sea. The Netherlands national team that won bronze at the 1912 Olympic tournament was said to have played in a recognizably 'British' style, 'relying more on science, combination and agility than on speed and hard rushes, especially as regards the play of the forwards. ${ }^{58}$ This may or may not have been a factor in improved form at international level, especially against Belgium, and in a famous first victory against England's amateurs in 1913, described by sports historian Allen Guttmann as the 'rite de passage of trouncing the English.' ${ }^{59}$ At this point and onwards through the First World War, however, any discernible Corinthian influence was largely residual. The Dutch press continued to show interest but there was growing awareness that the English club was in decline, 'a formerly famed name, whose glory after the split from the FA has really faded. ${ }^{\prime 60}$

\section{Corinthianism reconfigured: the 1920 s}

Yet the Corinthians and the sporting ideology that they represented, still had a part to play in the soccer politics of the Netherlands. On their return in 1922, they were greeted with enthusiasm. In part, this was because their arrival signified the normalization of Anglo-Dutch relations after the disruption caused by the war during which the Netherlands had remained neutral. The role of the London-based Anglo-Batavian Society, founded in 1920, in setting up the tour suggests that it was part of a wider process of post-war rapprochement. Now, the FA, at least, had abandoned its anti-neutralist stance; 'Holland-England football relations have finally been resumed and we can only rejoice at this. ${ }^{61}$ A sense of relief may have influenced how matches were reported; it was as if the conquering heroes of 1906 had been 
re-invented. 'The reputation which precedes these English amateurs has certainly not been over-exaggerated', a local newspaper noted after the first match - a 5-2 win over Dutch champions Be Quick at Groningen: '[with] mathematical precision the ball went from foot to foot, from head to head, and this with a speed and thoroughness that verged on the perfect. ${ }^{62}$ De Telegraaf marked the occasion by interviewing the famous Austrian coach and referee Hugo Meisl who had witnessed the performance. 'Nothing has changed', he reassured them, '[the] Corinthians still represent the highest school of football. ${ }^{63} \mathrm{~A}$ further victory against a representative team of Dutch students followed and the tour finished a day later with a match against the Swallows who beat the visitors 1-0. 'The Swallows played fine football', recalled Norman Creek, a member of the touring party, 'and while the Corinthian defence was in good form the forwards never really got going.' Yet Dutch newspapers were inclined to be generous. If not at their best at the end of a five match tour - they had arrived in the Netherlands after two matches in Denmark - the Corinthians were superior in technique, 'which the connoisseur often enjoys more than the result of the match. ${ }^{64}$

The idea that nothing had changed since 1906 was an illusion. At home the Corinthians were finding it 'almost impossible to get Saturday games against the best professional teams', an indication of their reduced status in English soccer. ${ }^{65}$ Moreover, those in the Netherlands who looked to them for inspiration were themselves coming under pressure in the early 1920 s. Though never as socially exclusive as cricket, soccer in the early years of the century had been played mainly by students and young middle-class men from the 'better milieus' in the west. The mobilization of the Dutch army in response to the threat of war sent many enthusiasts to parts of the country where the game had yet to take hold thus facilitating wider dissemination and participation. Whereas there had been only 80 NVB-registered clubs in 1901 and 346 in 1911, there were 1,188 by 1921, of whom the socially-exclusive first wave comprised a diminishing proportion as the number of volksclubs increased. ${ }^{66}$ British troops from the First Royal Naval Brigade, interned for the duration at Groningen after retreating across the border from Belgium, assisted in this process. 'Many enjoyable away matches have taken place', their Camp Magazine reported in May 1917, 'and so far as Soccer is concerned there is hardly a town of any importance that they have not visited. ${ }^{67}$ In inviting the Corinthians to the Netherlands the Swallows - praised as much 
for taking this initiative as for defeating the tourists on the field of play - were effectively shoring up the position of the pre-1900 clubs from which it drew its players as the balance of power in Dutch soccer shifted against them. Whereas the national championship had once been dominated by HVV and Rotterdam Sparta, newer and less socially-exclusive clubs, such as Ajax, Go Ahead Deventer, Be Quick Groningen and NAC Breda, had taken the title in the seasons immediately preceding the first post-war visit of the Corinthians.

There were other indications that Dutch soccer's old guard was under pressure by the early 1920s. Gentlemanly footballers in the Netherlands had sufficient means to play without seeking compensation for 'broken time' but as soccer became more popular it became difficult to keep money out of the game. One anxious commentator, as early as 1910, had referred to Dutch football as being, 'purely amateur' at heart but 'contaminated by professional airs' and in 1917 the NVB had found it necessary to clarify its position on allowable travelling expenses following reports of excessive payments to players. ${ }^{68}$ While holding the line on amateurism, the NVB faced a significant challenge in 1921 when 16 players from Ajax, Blauw Wit and De Spartaan, including almost all of the Amsterdam-based Dutch internationals, agreed to form a professional club, arguing that it was perverse that outsiders should make money from soccer while players went unrewarded and were even denied compensation for lost income. They also resented the increasing demands made on them by the NVB and the clubs, especially the extension of the playing season in order to boost revenue. Professionalization, by placing the club-player relationship on a contractual basis, offered a degree of protection and also the prospect of raising the standard of soccer in the Netherlands. Ajax and Blauw Wit quickly distanced themselves by affirming their allegiance to amateurism and it was soon evident that the initiative would fail but the tensions which had motivated the players remained unresolved. ${ }^{69}$ Possibly the most significant aspect of this episode was that it provided opportunities to question the prevailing amateur ethos, prompting Nieuwe Rotterdamsche Courant, for example, to argue, albeit 'very cautiously', for the introduction of professionalism and for De Tijd to point to England as a place where 'professional football, as well as amateur football, is held in high regard. ${ }^{70}$ 
Much of the discourse surrounding this issue reflected anxieties generated by changes in Dutch society and their impact on the game. With participants increasing rapidly, from around 10,000 in 1914 to 50,000 in 1919 and 100,000 in 1930, Dutch soccer was increasingly dominated by lower-middle class or working-class clubs. Moreover, the Netherlands was certainly not immune from the socio-political tensions that engulfed other industrial societies in the early 1920s. ${ }^{71}$ Van Bottenburg, in particular, sets evidence of antipathy between the old and new clubs within this frame. 'With the rise of working-men's soccer, a class struggle ensued,' he argues. 'Elites were averse to competing against people they would shun in everyday life.' As complaints of foul play and unsporting behaviour by the volksclubs and their players proliferated, sports enthusiasts attached to the socially-elite clubs became increasingly disinclined to engage in 'the sweaty pursuit of football.' Some gave up sport altogether or concentrated on cricket; others switched to the more gentlemanly winter pursuits of hockey or rugby union. In these circumstances the influence of pre-1900 clubs at the NVB and in Dutch soccer generally was diminishing. This was evident from the changing composition of the national team with players from these clubs increasingly less likely to be selected than before $1918 .^{72}$

De Telegraaf, reviewing the 1922 tour, reminded readers that the Corinthians were no ordinary club. Membership was 'a special honour' and 'every club in England considers it a privilege to play against them.' There were still lessons that the Dutch could learn from their visitors, especially regarding attacking play and superior technique on the ball. The tour, however, had a 'deeper meaning' and this became apparent in the months that followed. ${ }^{73}$ Just as the 1906 visit had prompted those seeking to emulate their English masters to set up De Zwaluwen so the April 1922 tour paved the way for the Nederlandsche Corinthians, founded in November with the object 'above all, [of] upholding amateur views and principles and making the case for soccer in the circles that are gradually withdrawing from active participation. ${ }^{74}$ At a subsequent meeting it became clear that supporters of the new movement, based mainly at HVV and some other pre-1900 clubs, were disenchanted with the existing 'odious' league system, arguing that it made excessive demands on players and discouraged 'good-natured' sport. One advocated 'parallel divisions'; another favoured a voluntary competition 'in which one could choose one's own opponents. ${ }^{75}$ As in 1906 
Corinthianism was being appropriated to serve a particular purpose in the Netherlands. The emphasis now was on protecting the interests of an elite who wished to play 'civilized' soccer against opponents of similar social standing to themselves. In the socio-political climate of the early 1920s this was highly provocative. Het Volk was outraged that a player's ability would be considered less important than having a 'genteel accent' and being 'chic in dress and in the cut of their jacket.'76 Ajax urged clubs to 'cold shoulder' the new movement, declaring that '[it] should offend the honour of every right-minded sportsman to play against an opponent whom he knows regards him as an inferior.' As for the Swallows, they eventually issued a circular distancing themselves from the 'Class War' which their rivals seemed determined to inflict on Dutch soccer. ${ }^{77}$

The Corinthians were almost certainly aware of these developments and would have recognized the concerns raised by their Dutch counterparts. Stanley Harris, a former player, writing to The Times in October 1922, had drawn attention to the 'considerable apprehension [that] exists at the present time lest "sportsmanship" in sport should become a lost quality. ${ }^{78}$ The preservation of amateurism in its 'purest' (i.e. Corinthian) form was very much on the agenda as the FA contemplated whether or not to send a team to the 1924 Olympic tournament, with the debate focusing largely on the contentious issue of broken-time payments. ${ }^{79}$ Now was the time for Corinthians of all nationalities to come together in defence of purist amateurism. Yet, in making arrangements for the tour, the English visitors had to negotiate their way very carefully around the rift which now manifested itself, albeit temporarily, among those who saw themselves as the guardians of amateurism in Dutch soccer. Inspired by the Corinthians of 1906, De Zwaluwen were motivated primarily by a desire to raise playing standards and to improve the performance of the national team. They were aligned with key figures like Hirschman and J.W. Kips at the NVB who were anxious to prevent the Nederlandsche Corinthians from precipitating a damaging split. Keeping the new movement and its flagship club in check meant denying it the legitimacy that a fixture against the most celebrated amateur footballers in the world would have conferred. The Corinthians, having originally agreed to play the new club, eventually complied with the wishes of the NVB and De Zwaluwen, no doubt much to the satisfaction of Voorwaarts which had argued that such a match would give the class warriors 
unmerited recognition. ${ }^{80}$ Arriving in the Netherlands after two defeats in Belgium, they eventually played against Willem II (1-5), Dutch Universities (2-0), the Swallows (2-0) and a Rotterdam representative team (1-2); the 30,000 crowd for the match against the Swallows indicating that the club's reputation still counted for something.

As far as Dutch soccer was concerned the most important outcome of the 1923 tour was that the Corinthians appeared to have sided with the conciliatory stance of the NVB and De Zwaluwen rather than with the aggressive elitism of the new movement. Yet their decision, later in the year, to confer honorary life membership on the president of the Nederlandsche Corinthians suggests that they were not unsympathetic to what it was trying to achieve. ${ }^{81}$ This was confirmed in 1924 when 'a football team of Corinthians' agreed to play their Dutch namesakes at The Hague, with the proceeds (minus expenses) benefiting the Anglo-Batavian Society, again instrumental in making the arrangements. This match, a 11 draw which went unreported in the English press, would have involved negotiations between the host club and the NVB, the governing body's approval being required for an international fixture. ${ }^{82}$ It signalled the end of hostilities between the NVB and the Dutch Corinthian movement, now no longer seen as a significant threat. Three years later, Jasper Warner, referring to the Swallows and the Dutch Corinthians, could claim that that there is no more rivalry between the two.' ${ }^{\prime 83}$ Thereafter, the Nederlandsche Corinthians kept the flame of elite amateurism flickering through their magazine De Corinthian and by promoting the game at the universities, but were effectively in retreat from this point and folded during the Second World War. ${ }^{84}$

Hopes that the Dutch and English Corinthians would meet annually quickly faded. It was not until 1933 that the English gentlemen amateurs returned. The Dutch press was generally well-disposed towards them in the 1920s but, as their play declined and the gap between English 'masters' and Dutch 'students' narrowed, it was more inclined to point out deficiencies. Reporting on the Dutch Universities match in 1923, Algemeen Handelsblad had hinted that Corinthians full-backs had resorted to desperate measures when outpaced by speedy forwards: 'These backs played like professionals: that is all we want to say about it. ${ }^{85}$ Yet there was a reluctance to suggest that the glory days were over. Dutch soccer had made a substantial moral investment in the Corinthians over the years and criticism was 
restrained. Het Sportsblad, covering the draw with Nederlandsche Corinthians in 1924, noted that the visitors 'were not as strong as one would have wished ... but that a poor Corinthian is still as strong as many a good First Division Dutch player. ${ }^{86}$ Even when they were well beaten by the Swallows (5-1) on their return in April 1933, De Revue der Sporten was inclined to forgiveness, attributing the scale of the defeat to playing under floodlights for the first time. ${ }^{87}$

Thereafter the mystique surrounding the Corinthians evaporated. A further threematch tour undertaken in September 1933 resulted in three defeats, 'the first time the club had ever failed to win a single game on a proper tour involving more than a single match. ${ }^{\prime 88}$ De Telegraaf reported that at Arnhem, where they lost 2-1 to Vitesse, the Corinthians were 'below the expected standard.' At HVV, where they lost 7-2, according to De Revue der Sporten, 'the defence was ... so bad that people wondered if they were the representatives of the famous Corinthians team. ${ }^{89}$ A 6-2 defeat to the Swallows in the final match simply underlined that, as far as the gentlemen amateurs of the Netherlands were concerned, there was now little to be gained from matches with a club so obviously in decline. This impression could only have been confirmed by subsequent reports from London arguing that the drift to rugby in England's public schools had cut off the supply of young talent which the club needed to secure its future. The best that the Corinthians could offer, it was observed, after a 7-2 defeat by Tottenham Hotspur's reserve side, was 'a bad imitation of the professional game and the tactics which professional players use. ${ }^{\prime 90}$ For a club that was supposed to represent the best of gentlemanly amateurism, this was the ultimate insult.

\section{Conclusion}

Tours of the Netherlands by the Corinthians followed a pattern with which English gentlemen amateurs became familiar as the standard of soccer played by opposing teams improved. At first they were the teachers but by the 1930s they were the somewhat overmatched pupils. ${ }^{\prime 91}$ They played a significant part in the transnational diffusion of the association game from England to the Netherlands but were not pioneers in this respect as other clubs, albeit less illustrious, had been visiting since the 1890 s. Yet the importance of their reputation as the world's leading amateur club should not be underestimated. A visit from the Corinthians in 1906, while they retained a significant symbolic presence in English 
football, conferred status and respectability on Dutch soccer and helped to underpin its growing popularity. It also supplied a model which those who were anxious to improve standards could emulate through the agency of De Zwaluwen, their own Corinthians-style club, without compromising the NVB's commitment to amateurism. Even in the 1920s a match against the Corinthians could still be regarded as a prestige fixture.

Their impact on Dutch soccer would have been greater had it not been for the FAAFA split which denied them opportunities to strengthen the connections that had been made in 1906. It was this - and the disruption of the First World War - that delayed a second visit until 1922, by which time the Corinthians were in decline. English influences on the Netherlands remained important, not least that of the Royal Naval Brigade between 1914 and 1918, but there was no direct exposure to the socially-exclusive version of amateur soccer that the Corinthians embodied. The appointment of Chadwick to coach the Dutch national side suggests an appreciation of the technical proficiency and tactical awareness of English professionals. By the mid-1920s, after Ajax had invited Bolton Wanderers and Leeds United to Amsterdam, the NVB was prepared to concede that such clubs 'represented almost the best English game' and that there was 'much to learn from these football-workers'. ${ }^{92}$ As for the Corinthians, the social aspect of touring became increasingly important. Creek described the 1923 tour of the Low Countries, despite some poor results, as 'one of the jolliest fortnights imaginable. ${ }^{93}$ This was incompatible with the pursuit of excellence on the field and they could no longer be used to demonstrate how the game should be played. When Ajax visited London in 1934 they showed no interest in the Corinthians but asked to watch Arsenal play Chelsea. ${ }^{94}$ This was an indication of the direction in which Dutch soccer was moving, albeit rather slowly.

It was, however, not just soccer which characterized this particular transnational cultural exchange for the Corinthians were perceived as the representatives of gentlemanly amateurism. As McDowell has observed in relation to Queens Park, touring meant 'communing with the broad church of European amateur sport.' ${ }^{\prime 5}$ This resonated with a powerful constituency within Dutch soccer, located mainly at the pre-1900 clubs and at the NVB, which invested heavily in the mystique surrounding their famous English visitors. In the 1920s, as more people took up soccer, the Corinthians served a useful purpose as this 
faction looked for ways of preserving its influence while ensuring that soccer remained an attractive recreational activity for those who saw themselves as gentlemen and were inclined to avoid contact with their social inferiors in the new volksclubs. In this context it was the social exclusivity of Corinthian amateurism that appealed and the Nederlandsche Corinthians, founded after the first post-war tour in 1922, became the standard-bearers for this reactionary movement. Though the club had a limited impact, the purist amateurism favoured by the Corinthians remained the default position of the NVB which continued to resist broken-time payments and other reforms favoured by the newer clubs. When, in 1933, despite minor amendments to the broken-time rules, this policy became clear, it was described by socialist newspaper Het Volk as 'a black day for Dutch football' in that the selfinterest of the socially-elite clubs had triumphed. ${ }^{96}$ Professionalization remained a remote prospect in the Netherlands and was not sanctioned until 1954.

Finally, what does this examination of the tours undertaken by one English club in the Netherlands add to our understanding of transnational connectivity, arguably the foundation on which the edifice of soccer globalization has been constructed? Primarily, it confirms our understanding of bilateral connections as complex phenomena not readily encompassed by simplistic export-import explanations. The tours are best understood as sites of cultural interaction where English gentlemanly amateurism was first adopted and then adapted to meet the requirements of a peculiarly Dutch agenda. In the Netherlands, the visitors supplied a symbolic presence around which certain factions could rally and gave shape to the particular causes to which they attached themselves. Thus, in 1907, when disappointing performances by the national team prompted concern, the Corinthian model to which the Dutch had so recently been exposed was utilised to formulate a response in the form of De Zwaluwen. In 1922, a different aspect of Corinthianism was taken up as the old order in Dutch soccer sought to shore up its position via social segregation. What this suggests is that transnational connectivity led to cultural interaction characterized by selective adaptation. When it was announced in 1939 that the Corinthians could no longer function independently and were amalgamating with the Casuals, Algemeen Handelsblad lamented the death of a club that had represented 'amateurism in its purist form. ${ }^{97}$ The 
tourists had helped to shape the development of soccer in the Netherlands but only because the hosts had been able to use Corinthianism to meet their own particular needs.

\section{NOTES}

\footnotetext{
${ }^{1}$ The Sportsman (London), 13 April 1906.

2 De Telegraaf (Amsterdam), 18 April 1906, (O). Dutch newspapers often produced separate morning
} (Ochtend) and evening (Avond) editions; hereafter denoted by $(\mathrm{O})$ and $(\mathrm{A})$.

${ }^{3}$ B.O. Corbett, (ed.), Annals of the Corinthians Football Club (London: Longmans, Green \& Co., 1906), pp.vi-vii.

4 Maarten van Bottenburg, 'Beyond diffusion: Sport and its remaking in cross-cultural contexts', Journal of Sport History, 37, no. 1 (2010), 43.

${ }^{5}$ Bill Murray, The world's game: A history of soccer (Urbana, ILL: University of Illinois Press, 1998), 22.

${ }^{6}$ Richard Giulianotti and Roland Robertson, Globalization \& football (London: Sage, 2009), 29.

7 van Bottenburg, 'Beyond diffusion', 49-50; Matthew Taylor, 'Editorial - sport, transnationalism, and global history', Journal of Global History, 8, no.2 (2013), 204-05; 'Football's engineers? British football coaches, migration and intercultural transfer, c.1910-c.1950s', Sport in History, 30, no.1 (2010), 140-43.

${ }^{8}$ Athletic News (Manchester), 2 April 1906; The Sportsman, 12 April 1906.

9 Taylor, 'Sport, transnationalism, and global history', 204.

${ }^{10}$ Geoff Hare, 'What is an international match? French football clubs and the earliest "international matches"', Sport in History, 35, no. 4 (2015), 501.

11 Matthew McDowell, 'Queen's Park FC in Copenhagen, 1898-1903: Paradoxes in early transnational amateurism', (2014), 1-18; http://www.idrottsforum.org/mcdowell140514, (accessed 19 April 2016).

12 Tony Mason, 'Middle-class wanderers and working-class professionals: the British and the growth of world football, 1899-1954', in Classes, cultures and politics: Essays on British history for Ross McKibbin, ed. Clare V.J. Griffiths, James J. Nott and William Whyte (Oxford: Oxford University Press, 2011), 121-22.

${ }^{13}$ Mike Huggins, 'Sport, tourism and history: current historiography and future prospects', Journal of Tourism History, 5, no.2 (2013), 124. 
${ }^{14}$ See Richard Holt, 'Amateurism and its interpretation: the social origins of British sport', Innovation, 5, no.4 (1992), 19-22.

${ }^{15}$ Lincoln Allison, Amateurism in sport: an analysis and a defence (London: Frank Cass, 2001), 11-12; see also Matthew P. Llewellyn and John Gleaves, The rise and fall of Olympic amateurism (Urbana, ILL, University of Illinois Press, 2016), 33.

${ }^{16}$ Maarten van Bottenburg, Global games (Urbana, ILL: University of Illinois Press, 2002), 101-04.

17 'Engeland', Voetbal Almanak 1907/08 (Amsterdam: Nederlandsche Voetbalbond, 1907), 245.

18 George Wyndham, The development of the state: Being an address delivered to the students of the University of Glasgow, November 1904 (London: Archibald Constable \& Co. Ltd., 1904), 57.

${ }^{19}$ See research papers relating to William Quash; London Borough of Barking and Dagenham Archives and Local Studies Service, ACQ 20013/064. For the status of the 1900 Olympic tournament and the reason why 'some of the athletes returning home were surprised to learn that they had just competed in the Olympic Games', see Allen Guttman, The Olympics: a history of the modern games, (2 ${ }^{\text {nd }}$ ed.), (Urbana, ILL: University of Illinois Press, 2002), 21-22.

${ }^{20}$ Huggins, 'Sport, tourism and history', 124-25.

${ }^{21}$ Nancy W. Ellenberger, 'Constructing George Wyndham: narratives of aristocratic masculinity in fin-de-siècle England', Journal of British Studies, 39, no. 4 (2000), 498-99; also John Tosh, 'Domesticity and manliness in the Victorian middle class: the family of Edward White Benson', in Masculinities in Britain since 1800, ed. Michael Roper and John Tosh (London: Routledge, 1991), 67.

${ }^{22}$ van Bottenburg, Global games, 108.

${ }^{23}$ Cricket notes by the Rev. E.E. Lee, dated 19 January 1952; Worcestershire Archives and Archaeology Service, 899.19, BA 1223

${ }^{24}$ For details of these and other early tours see the very useful but not entirely reliable list compiled by Javier Garcia, British and Irish Clubs - Overseas Tours 1890-1939; http://www.rssf.com/tablesb/brit-ier-toursprewwii-html (accessed 3 May 2016).

${ }^{25}$ Morning Post (London), 14 February 1899.

${ }^{26}$ Algemeen Handelsblad (Amsterdam), 1 April 1899, (O); Corbett, Annals of the Corinthians, 111; F.N.S. Creek, A history of the Corinthian Football Club, (London: Longmans Green and Co., 1933), 76; Rob Cavallini, Play up Corinth: a history of the Corinthian Football Club (Stroud: Stadia, 2007), 85. 
${ }^{27}$ N. Lane ('Pa') Jackson, Sporting days and sporting ways (London: Hurst \& Blackett Ltd, 1932), 66; see also Corbett, Annals of the Corinthians, 10; Creek, History of the Corinthians, 4; Cavallini, Play up Corinth, 9.

${ }^{28}$ Stephen Koss, The rise and fall of the political press in Britain (London: Fontana, 1990), 42; Morning Post, 11 November 1898.

${ }^{29}$ See, for example, C.B. Fry, Life worth living: Some phases of an Englishman (first published 1939; London: Pavilion Books, 1986), 266; Edward Grayson, Corinthians \& Cricketers (London: Sportsmans Book Club, 1957), 28.

${ }^{30}$ For the club's history and its role in the development of the game see Terry Morris, In a class of their own: A history of English amateur football (Sheffield: Chequered Flag Publications, 2015), 164-73; Christian Koller and Fabian Brändle, Goal! A cultural and social history of modern football (Washington DC: Catholic University of America Press, 2015), 74-75; Matthew Taylor, The association game: A history of British football (Harlow: Pearson Education, 2008), 82-85; Tony Mason, Association football and English society 1863-1915 (Brighton: Harvester Press, 1980), 216-17.

${ }^{31}$ Athletic News, 1 January 1906.

${ }^{32}$ Algemeen Handelsblad, 22 December 1905, (A); De Telegraaf, 18 April 1906, (O); Nieuwe Rotterdamsche Courant (Rotterdam), 9 April 1923 (A).

${ }^{33}$ Algemeen Handelsblad, 10 December 1932, (A).

${ }^{34}$ N. Lane Jackson, 'The Corinthians', The Times (London), 26 October 1932.

${ }^{35}$ Athletic News, 19 April 1922.

${ }^{36}$ Cavallini, Play up Corinth, 138.

${ }^{37}$ Nieuwe Rotterdamsche Courant, 26 October 1920, (A); 6 April 1922, (A).

${ }^{38}$ C.B. Fry, "Character sketches', in Annals of the Corinthians, ed. Corbett, 33.

${ }^{39}$ Morris, Class of their own, 172-73; Cavallini, Play up Corinth, 36-37; Chris Bolsmann, 'South African football tours at the turn of the twentieth century: Amateurs, pioneers and profits', African Historical Review, 42, no.1 (2010), 96-97, 105.

${ }^{40}$ Corbett, Annals of the Corinthians, 115-17; Creek, History of the Corinthians, 76-77, 93-94, 96-97.

${ }^{41}$ Corbett, Annals of the Corinthians, 18-19; Morris, Class of their own, 173. 
${ }^{42}$ For more on early Dutch sports reporting see Nicholas Piercey, Four histories about early Dutch football: Constructing discourses (London: UCL Press, 2016), 107-38; also Ruud Stotvis, 'Een genre in beweging: De ongemakkelijke verhouding tussen sport en journalistiek', in Journalistieke cultuur in Nederland, ed. Johannes Bardoel (Amsterdam: Amsterdam University Press, 2009), 191-207; Cornelis Miermans, Voetbal in Nederland: Een onderzoek naar de maatschappelijke en sportieve aspecten (Assen: Van Gorcum, 1955), 206-09. A report on the forthcoming South African tour appeared in Algemeen Handelsblad, 5 June (A).

${ }^{43}$ Algemeen Handelsblad, 9 January 1898, (O); De Telegraaf, 27 November 1903, (A).

${ }^{44}$ Algemeen Handelsbad, 8 April 1904, (A).

${ }^{45}$ Algemeen Handelsblad, 8 February 1906 (A); Nieuws van der Dag (Amsterdam) 20 February 1906.

${ }^{46}$ Algemeen Handelsblad, 10 March 1906, (0).

${ }^{47}$ Het Sportsblad (Amsterdam), 19 April 1906.

${ }^{48}$ Creek, History of the Corinthians, 76-77.

49 Timmis quoted in De Telegraaf, 22 April 1906.

${ }^{50}$ Rotterdamsche Nieuwsblad (Rotterdam), 21 April 1906.

51 Het Sportsblad, 17 May 1906. See also Matty Verkammen, Oranje toen en Nu: 1905-1914, 2000/2001 (Houten: Premium Press, 2001), 33.

52 Smith quoted in Grayson, Corinthians \& Cricketers, 31.

${ }^{53}$ Het Sportsblad, 18 April 1907.

${ }^{54}$ Hirschman quoted in P.A. de Haan, 'Onze levensloop', in Gedenboek uitgegeven ter gelegenheid van det 20-jarig bestaan der Algemeene Nederlandsche Voetbalvereeniging "De Zwaluwen" (Dordrecht: Hanskes, 1927), 33.

${ }^{55}$ Het Sportsblad, 8, 15 August 1907.

56 Dilwyn Porter, 'Revenge of the Crouch End Vampires: The AFA, the FA and English football's "Great Split", 1907-14', Sport in History, 26, no.3 (2006), 422-23.

${ }^{57}$ Llewellyn and Gleaves, Rise and fall of Olympic amateurism, 48.

58 The Official Report of the Olympic Games of Stockholm 1912 issued by the Swedish Olympic Committee, ed. Erik Bergvall (Stockholm: Wahlström \& Widstrand, 1912), 501; http://www.library.la84.org/6oic.Official/Report/1912/1912part2/pdf (accessed 1 September 2016). 
${ }^{59}$ Allen Guttmann cited in van Bottenburg, Global Games, 111.

${ }^{60}$ De Telegraaf, 11 August 1911, (O).

${ }^{61}$ Algemeen Handelsblad, 23 April 1922 (O); De Telegraaf, 25 April 1922, (A).

${ }^{62}$ Nieuwsblad van het Noorden (Groningen), 21 April 1922.

${ }^{63}$ De Telegraaf, 21 April 1922, (0).

${ }^{64}$ Creek, History of the Corinthians, 93-94; De Telegraaf, 24 April 1922.

${ }^{65}$ Creek, History of the Corinthians, 46-52; Cavallini, Play up Corinth, 123-30.

${ }^{66}$ Miermans, Voetbal in Nederland, 122; Tabel 1, 221.

${ }^{67}$ The Camp Magazine: being the periodical of the First Royal Naval Brigade, interned in Holland, May 1917, 2; http://www.prisonersofwar1914-1918documents.com/downloads---section-4.php (accessed 31 August 2016).

${ }^{68}$ Nieuwe Rotterdamsche Courant, 15 February 1910, (O); 13 June 1917, (A).

${ }^{69}$ Nieuwe Rotterdamsche Courant, 9 August 1921 (A); see also Frans van Niewenhof, Voetbalgeschiedenis, part 2, (Gouda: Voetbal International Boeken, 2014), 13-17.

${ }^{70}$ Nieuwe Rotterdamsche Courant, 10 August 1921, (0); De Tjid ('s-Hertogenbosch), 28 August 1921.

${ }^{71}$ See J.C.H. Blom, 'The "Modernization" of the Netherlands (1870-1918)', in J.C.H. Blom and E. Lamberts, History of the Low Countries, $2^{\text {nd }}$ edn., (Basingstoke: Palgrave Macmillan, 2012), 428.

${ }^{72}$ See Van Bottenburg, Global games, 110-14.

${ }^{73}$ De Telegraaf, 25 April 1922, (OA).

${ }^{74}$ Nieuwe Rotterdamsche Courant, 3 December 1922, (0); statement outlining the constitution of the new club.

${ }^{75}$ De Telegraaf, 31 December 1922.

${ }^{76}$ Het Volk (Amsterdam), 18 December 1922.

${ }^{77}$ Algemeen Handelsblad, 4 March 1923, (A); Het Volk, 3 March 1923.

${ }^{78}$ The Times, 24 October 1922; see also the Bishop of Durham's letter in favour of the 'purification of sport', 11 November 1922. 
79 Matthew P. Llewellyn, 'The curse of the shamateur', International Journal of the History of Sport, 28, no.5 (2011), 798-800; for the debate within the Olympic movement on amateurism in the 1920s see Llewellyn and Gleaves, Rise and fall of Olympic amateurism, 63-73.

${ }^{80}$ Voorwaarts (Amsterdam), 5, 24 March 1923.

${ }^{81}$ Algemeen Handelsblad, 25 December 1923, (O); Creek, History of the Corinthians, 267.

82 Anglo-Netherlands Society, London: Anglo-Batavian Society, Minutes of Council, 27 March, 6 November 1924; De Telegraaf, 9 April 1924, (O). It may or may not be significant but this match is not mentioned at all in the histories of the Corinthians club by Creek (1933) and Cavallini (2007).

83 Jasper Warner, 'Het Nut der Zwaluwen', Zwaluwen Jubileeboek, 9.

${ }^{84}$ Matty Verkammen, Orange toen en Nu: 1914-1926, 2001/2002 (Narden: Strengholt, 2002), 88. De Corinthian merged with De Revue der Sporten in the 1930s.

${ }^{85}$ Algemeen Handelsblad, 8 April 1923, (0).

${ }^{86}$ Het Sportsblad, 24 April 1924.

${ }^{87}$ De Revue der Sporten/De Corinthian, 10 April 1933.

${ }^{88}$ Cavallini, Play Up Corinth, 192.

${ }^{89}$ De Telegraaf, 3 September 1933; De Revue der Sporten, 4 September 1933.

${ }^{90}$ De Telegraaf, 21 September 1933 (A); 13 November 1934 (A).

${ }^{91}$ Mason, 'Middle-Class Wanderers', 130-31.

92 Voetbal-Jaarboekje 1921-24 (Amsterdam: Nederlandsche Voetbalbond, 1924), 54-55.

${ }^{93}$ Creek, History of the Corinthians, 97.

${ }^{94}$ R.B. Alaway, Football all round the world (London: Newservice Ltd., 1948), 62.

95 McDowell, 'Queen's Park in Copenhagen', 3.

${ }^{96}$ Het Volk, 4 September 1933, (O).

${ }^{97}$ Algemeen Handelsblad, 7 January 1939, (O). 